\title{
Model of geothermal water deironing on the basis of a triangulation
}

\author{
Iwona Klosok-Bazan ${ }^{1, *}$, and Robert Olszewski ${ }^{2}$ \\ ${ }^{1}$ Opole University of Technology, Mechanical Department, Opole Mikolajczyka Str. 5, Poland \\ ${ }^{2}$ Warsaw University of Technology, Faculty of Geodesy and Cartography, Warsaw, Pl. Politechniki 1, Poland
}

\begin{abstract}
The main of this research was to recognize the efficiency of geothermal water deironing processes. To this, studies on a laboratory scale were conducted. In the paper the modeling of geothermal water deironing processes using new tool basis on triangulation has been used. Carrying out the analysis of potential possibilities of using geothermal water and taking economic aspects of water deironing processes into account, the authors of this article conducted research into the geothermal water deironing processes by adjusting existing knowledge on the removal of iron from cold groundwater. The conducted research confirmed the possibility of adjusting such processes to the treatment of geothermal water, but their effectiveness differs depending on the temperature and salinity of water, but this relation is not linear. The analyzes indicated that the best deironing effect was obtained for water whose salinity does not exceed 10 $\mathrm{g} / \mathrm{L}$ and the temperature $30^{\circ} \mathrm{C}$.
\end{abstract}

\section{Introduction}

Natural hot waters have been used since earliest time, and warm springs occur in many region of the world. Reservoirs of geothermal water are found in locations where the earth's heat is near enough to the surface so that water or steam can reach the top [1-3]. Geothermal waters quality is very diverse. Iron is one of the solute available as pyrite and pyrrholite from rock-forming constituents which usually is found at very low concentration levels [3]. Iron is not considered hazardous to humans health but it causes technological and esthetic problems. Iron present in the water at concentrations exceeding the level of $0.2 \mathrm{mg} / 1$, the following problems can occur: iron precipitates give water a reddish color when exposed to air; deposition of iron precipitates in the distribution system can reduce the effective pipe diameter and eventually clog the pipe; additionally aesthetic value of the equipment used in balneology and recreation lower because of the reddish residue [2-11]. Therefore, the water with iron should be treated in deironing processes. Iron removal by aeration and separation is a common method for removal of iron as from groundwater going into the public water supply system as well from geothermal water using for balneology [7-11].

Alternative processes, such as ion-exchange, oxidation with oxidizing agents including chlorine and potassium permanganate, filtering with activated carbon and other filtering materials, supercritical fluid extraction, bioremediation and treatment with limestone, have been proposed in order to facilitate the operation and allow the removal of high amounts of iron [7, 9].

The quality of the deironing process is a function of many factors changing in time $[3,4]$. Deironing processes of so-called cold water (water temperature up to $20^{\circ} \mathrm{C}$ ) are rather well known and broadly described in literature [7-9]. However, geothermal water deironing processes have not been the subject of so many studies, which induced the authors of this article to become interested in this issue. To bring up the problem, laboratory tests were conducted and the model of the process on the basis of a triangulation was made.

Triangulation is one of the methods of interpolation enable conversion of discrete data to a continuous form. It allows to test the properties of the mathematical field which is the model of continuous distribution of the quantitative feature of the phenomenon. Appropriately selected interpolation methods allow for development of the correct model of spatial distribution of a given phenomenon on the basis of the limited amount of source data. Interpolation is a numerical method which allows to define a so-called interpolation function in a given range which accepts the nominal values in set points called nodes. Interpolation is often applied in the experimental circumstances where you have a limited amount of data for definition of value relationships [12]. The interpolation algorithms can be applied both in two-, three- and multi-dimensional space [13]. The easiest example is the application of the linear function (Fig. 1) for interpolation of the value of dependant variable $(y)$ for a given value of independent variable $(x)$. The knowledge of the value of the (endogenous) variable

\footnotetext{
Corresponding author: i.klosok-bazan@po.opole.pl
} 
explained for two values of the explanatory (exogenous) variable is, in this case, sufficient to define y value for any $\mathrm{x}$ in a set field of considerations.

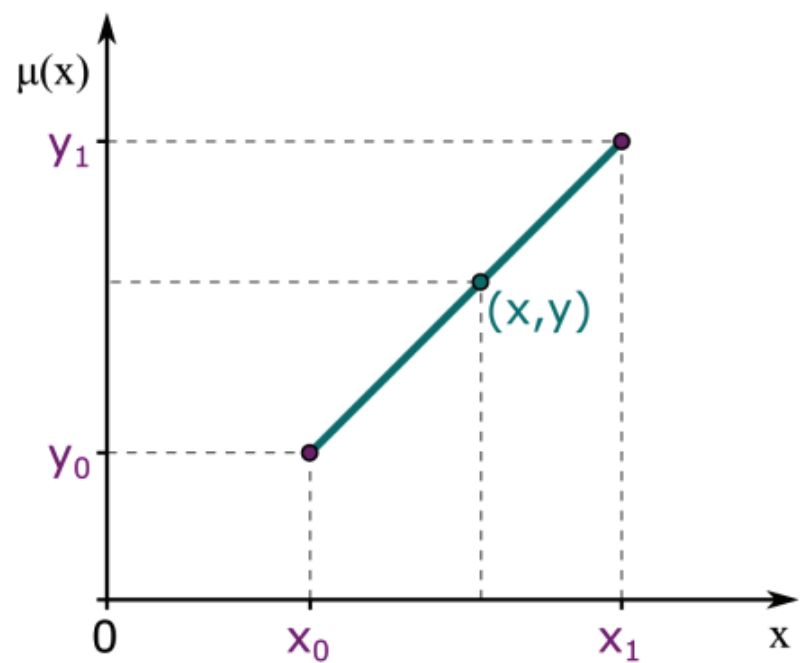

Fig. 1. Linear interpolation.

This easiest linear approach can also be applied in case of three-dimensional space. Having at disposal a set of irregularly distributed points with coordinates (xi, yi) and known values of attributes (zi), (e.g. height of the point above sea level, temperature, etc.), we can determine (interpolate) the demanded value in the external point of the area in coordinates defined in any manner (x,y) (Fig. 2).

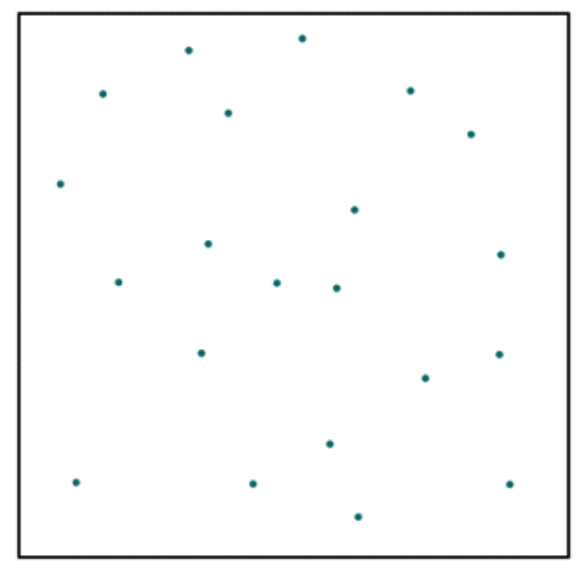

Fig. 2. The set of irregularly distributed measurement points.

Spatial interpolation with the linear method requires to set the network of Delaunay triangles or, in other words, determine Thiessen polygons on the basis of the set of measurement points. When they are determined in this manner, they fulfil the following conditions (Fig. 3): sums of triangle edges are the lowest and the sum of triangle heights is the lowest (the sum of length of two longest triangle edges is the lowest).

Delaunay triangles set (in X, Y, Z space) can be the basis for creation of the numerical space model - a so-called statistical surface [12] based on the set of distributed points (e.g. numerical model of topographical relief [13$15]$.
A so-called triangle irregular network (TIN) created in the process of Delaunay triangulation is, as a rule, transformed to the form of a regular network (most often with square mesh) which significantly facilitates the interpolation of spatial data (Fig. 4).

Determination of the interpolated value $\mathrm{ZP}$ in a given point $\mathrm{P}$ is performedby the application of a simple formula (Fig. 5) [12-15].

A)

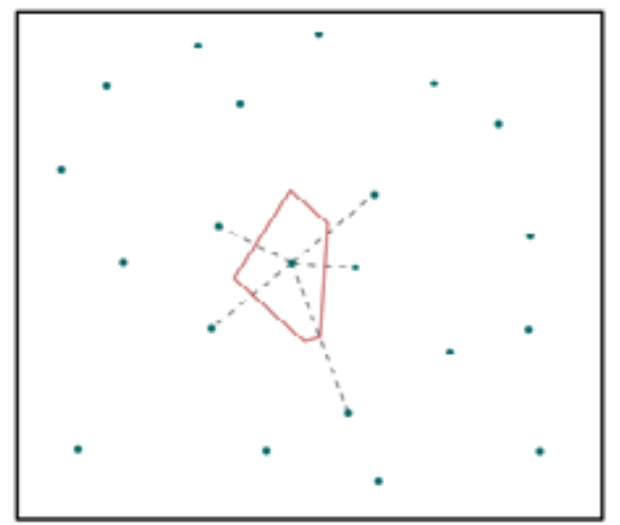

B)

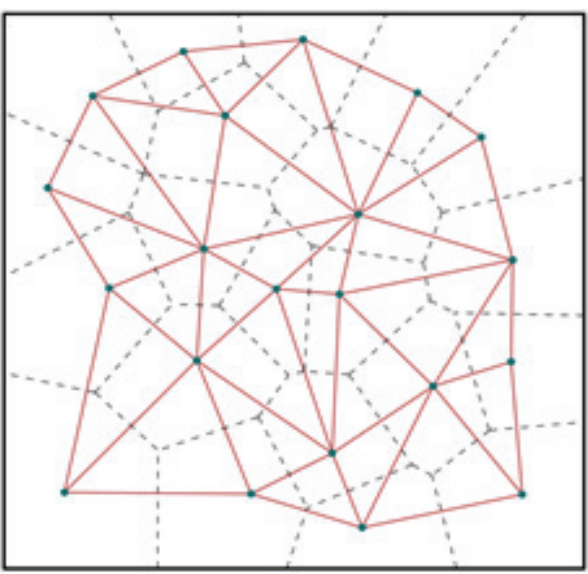

Fig. 3. Thiessen polygons (A) and Delaunay triangulation (B).

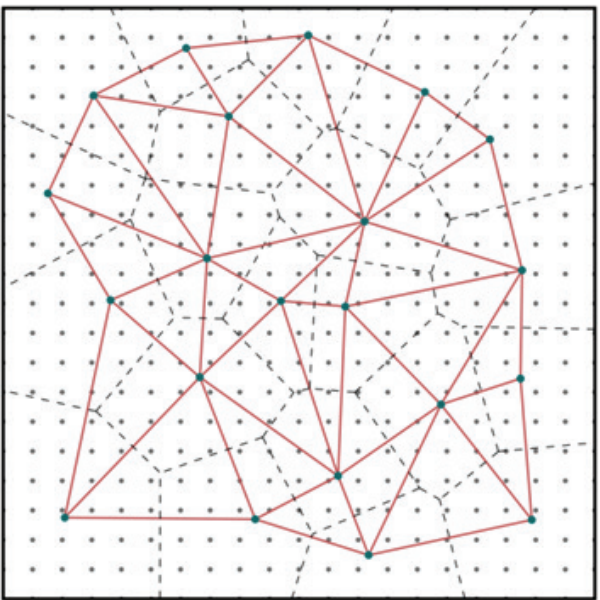

Fig. 4. The transformation of TIN model into a set of regularly distributed points. 

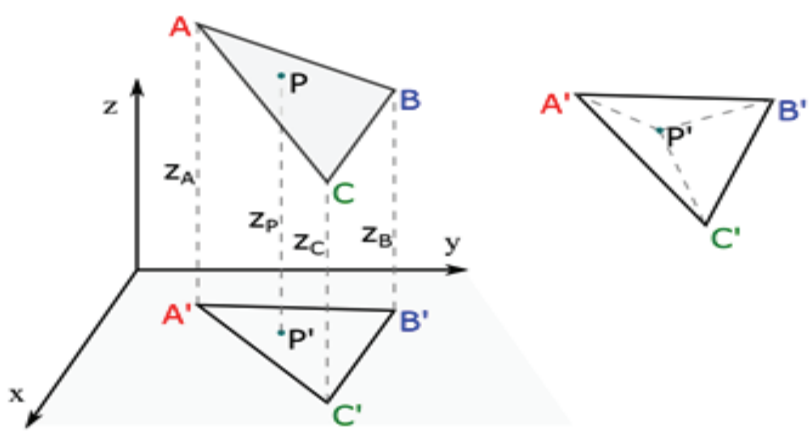

Fig. 5. Determination of the value of dependent variable in TIN model (interpolation linear function).

$$
z_{P}=\frac{z_{A} S_{A}+z_{B} S_{B}+z_{C} S_{C}}{S_{A}+S_{B}+S_{C}}
$$

where:

$\mathrm{S}_{\mathrm{A}^{-}} \mathrm{P}^{\prime} \mathrm{B}^{\prime} \mathrm{C}^{\prime}$ triangle field;

$\mathrm{S}_{\mathrm{B}}-\mathrm{P}^{\prime} \mathrm{A}^{\prime} \mathrm{C}^{\prime}$ triangle field;

$\mathrm{S}_{\mathrm{C}^{-}} \mathrm{P}^{\prime} \mathrm{A}^{\prime} \mathrm{B}^{\prime}$ triangle field.

\section{Materials and methods for laboratory tests}

The fundamental aim of this article was to develop the model of effectiveness of geothermal water deironing processes for balneological purposes on the basis of trangulation. For this reason the laboratory tests were conducted.

Geothermal water was prepared on the basis of distilled water and pure reagents added proportionally. Due to the composition of the analyzed geothermal water and brines, it was assumed that the salinity of model water will be obtained by dosing sodium chloride $(\mathrm{NaCl})$ and sodium sulphate $\left(\mathrm{Na}_{2} \mathrm{SO}_{4}\right)$ in range $4-150 \mathrm{~g} / \mathrm{L}$. After the preparation of saline water and the adjustment of $\mathrm{pH}$ to the level of natural geothermal water, i.e. $\mathrm{pH}=7.0 \pm$ 0.2 , water was heated until it reached the desired temperature.

The tests were conducted at constant, high concentration of iron, which was added to water in the form of pure iron sulphate in the amount $0.05 \mathrm{~g} / \mathrm{dm}^{3}$. It corresponded to the concentration of iron at the level of $18.42 \mathrm{mg} / \mathrm{dm}^{3}$. Bivalent iron in the form of $\mathrm{FeSO}_{4}$ was added to water with the assumed level of salinity, after the adjustment of $\mathrm{pH}$, to the sample in the water bath.

The temperature range applied in the test was $20-50{ }^{\circ} \mathrm{C}$. Samples prepared in such a way were subject to the aeration and, then, filtration processes after which iron was measured according to the standard PB-16/PL, edition no. 1 of 02.01.2014 Colorimetric determination of the total iron and divalent iron content in water containing small amounts of organic compounds using thiocyanate test.

The results obtained in the laboratory were used to create a model based on the previously described tool.

\section{Results and discussion}

The determination of optimum process zones for specific ranges of salinity and temperatures is extremely important (Fig. 6). It is necessary to provide an appropriate amount of oxygen so that the oxidation process could proceed correctly. In case of deironing of standard groundwater, this process should proceed effectively as $8-11^{\circ} \mathrm{C}$ is the temperature at which the oxygen solubility is relatively high $[7,9]$.

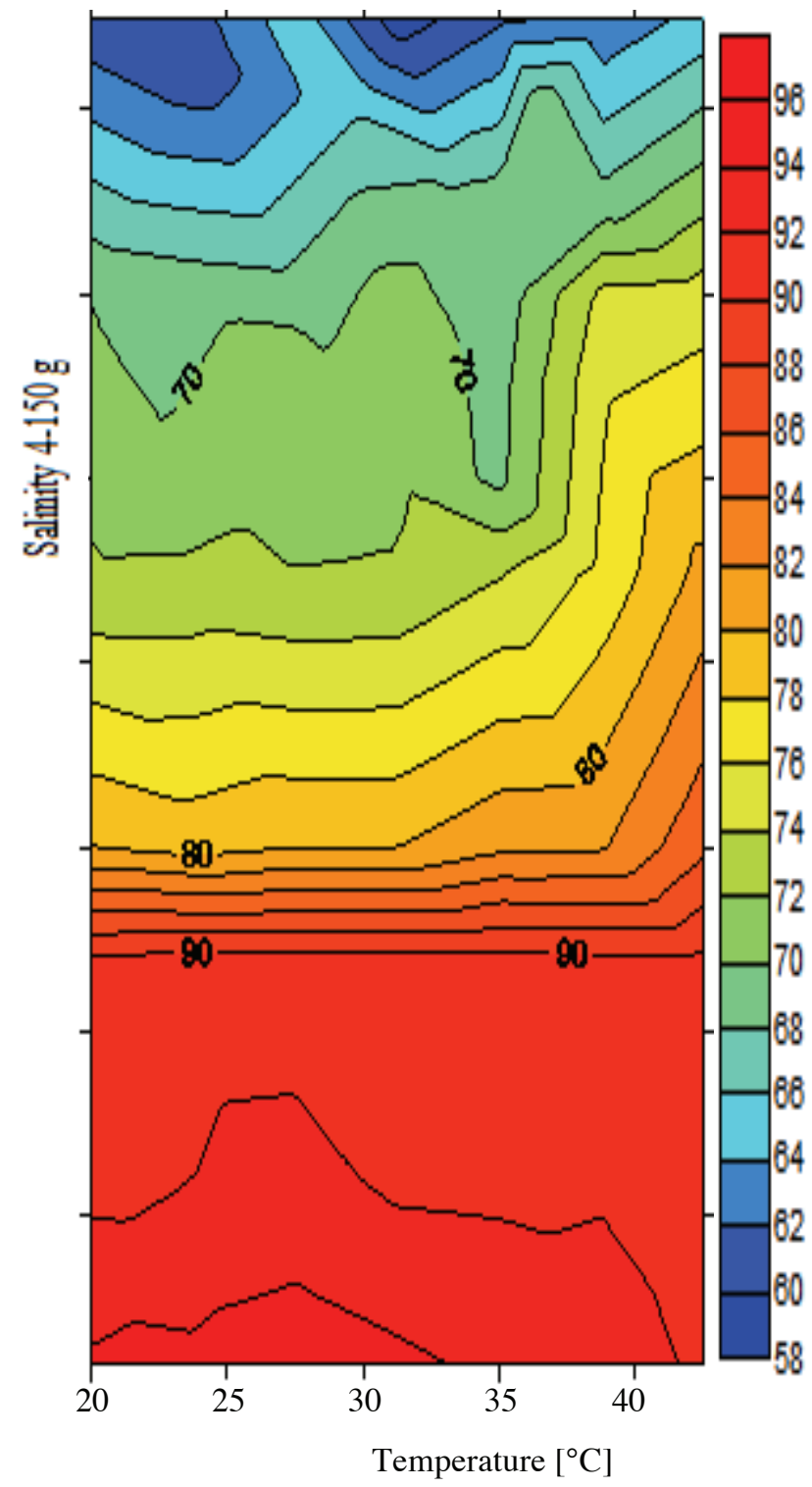

Fig. 6. Deironing process effectiveness model developed using triangulation model - thematic map.

The provision of an appropriate amount of oxygen dissolved in geothermal water with the temperature significantly exceeding $20^{\circ} \mathrm{C}$ is much more difficult. That is why the experimental determination of the time of reaction for the least optimum conditions (the highest salinity and the highest temperature) was the first, very important task to perform. As a result of the conducted analysis, it was stated that the aeration time should be about 30 minutes. The presented relation makes (Fig. 6) 
it possible to determine expected trends in the scope of changes in the effectiveness of deironing processes depending on changes in the temperature and salinity of treated water. From the presented relation it appears that the water deironing effectiveness decreases as the salinity increases, but this relation is not linear. The effectiveness of the deironing process is also affected by the second analyzed parameter, i.e. temperature. Figure 6 draws attention to the peculiar peninsula that was occurred when temperature range to $30^{\circ} \mathrm{C}$.

\section{Conclusions}

The conducted research confirmed the possibility of adjusting such processes to the treatment of geothermal water, but their effectiveness differs depending on the temperature and salinity of water. The removal of iron from water of salinity of $120-140 \mathrm{~g} / \mathrm{dm}^{3}$ at water treatment temperature $20-25{ }^{\circ} \mathrm{C}$ is the least effective while the highest effectiveness of the process was recorded for water of the lowest salinity level. The optimum process was reached at the temperature 25-35 ${ }^{\circ} \mathrm{C}$. The use of triangulation model based on quantity equations describing the relation between process variables allowed to predict the degree of iron removal in various cases depending on the process temperature rather precisely.

\section{References}

1. W. Górecki and another, Atlas of Geothermal Resources of Paleozoic Formations in the Polish Lowlands, Kraków (2006)

2. A.J. Ellias, W.A Mahon, Chemistry and Geothermal Systems. Academic Press, New York (1977)

3. J.L. Burguera, M. Burguera, C.E. Rondon, Anal. Chim. Acta 366 (1998)

4. I. Klosok-Bazan, Ochrona Srodowiska 36, 2 pp. 4346 (2014)

5. S. Armannson, J Pet. Sci. Technol. 33, 1 pp. 181188 (1981)

6. I. Klosok-Bazan, A. Sowa, Operational problems associated with the high iron concentration in thermal waters used for balneology. Proceedings of 15th International Multidisciplinary Scientific GeoConference SGEM, Albena, pp. 469-476 (2015)

7. A. Kowal, M. Świderska-Bróż, Oczyszczanie wody, Wydawnictwo Naukowe PWN, Warszawa (1997)

8. I. Klosok-Bazan, Modeling of geothermal water deironing processes using artificial neural networks. Proceedings of 16th International Multidisciplinary Scientific Geo Conference SGEM, Albena, pp. 187193 (2016)

9. R.D. Letterman, Water quality and treatment. A handbook of community water supplies. McGrawHill Book Company (1999)

10. Ch. Bong-Yeon, Process Biochem. 40 pp. 3314$3320(2005)$

11. I. Klosok-Bazan, Analisys of Recreational Use and Treatment Possibilities of Geothermal Water Taken from Sandstone Layer in Opole City. Proceedings of 16th International Multidisciplinary Scientific Geo Conference SGEM, Albena, pp. 27 - 33 (2016)

12. A.H. Robinson, Elements of Cartography, John Wiley\&Sons (1995)

13. Z. Kurczyński, R. Preuss, Podstawy fotogrametrii, Oficyna Wydawnicza Politechniki Warszawskiej, Warszawa (2000)

14. A. Buczek, R. Olszewski, Studium możliwości koherencji komponentów TOPO i NMT Bazy Danych Topograficznych, Archiwum Fotogrametrii, Kartografii i Teledetekcji 17b, (2000)

15. M-J. Krak, F. Ormeling, Kartografia. Wizualizacja danych przestrzennych, Wydawnictwo Naukowe PWN, Warszawa (1998) 